\title{
ANALISIS COVER ARTWORK ALBUM-ALBUM GIGI BAND
}

\section{GIGI BAND'S ALBUM COVER ARTWORKS ANALYSIS}

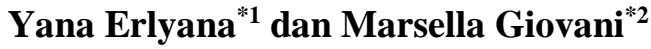 \\ ${ }^{1}$ Dosen Program Studi Desain Komunikasi Visual Universitas Bunda Mulia \\ ${ }^{2}$ Mahasiswa Program Studi Desain Komunikasi Visual Universitas Bunda Mulia \\ Diterima: 2 Oktober 2018 /Disetujui: 12 Oktober 2018
}

\begin{abstract}
Motivated by a long dicography of GIGI Band, this research was made to analyze cover artworks from their whole catalogue. This research used both design theories and another related theories, hopping that results of this study particulary useful for designers and business people who will make similiar works. This research uses qualitative method which deliver descriptive data of cover artwork design and its information which is aligned with the theory and literature used.The results of research is the form of analysis of each cover artwork from GIGI Band's albums which consist of visual attractiveness analysis and practical appeal on every artwork.
\end{abstract}

Keywords: Cover, Artwork, GIGI, Album

\section{ABSTRAK}

Dimotivasi oleh panjangnya diskografi band GIGI, penelitian ini dibuat untuk menganalisis cover artwork dari keseluruhan catalog mereka. Penelitian ini menggunakan baik teori desain maupun teori lainnya yang berhubungan, dengan harapan hasil dari pembelajaran ini dapat berguna bagi desainer serta pebisnis yang hendak melakukan pekerjaan yang sama. Penelitian ini menggunakan metode kualitatif yang menyajikan data deskriptif dari desain cover artwork dan informasinya yang berkesinambungan dengan teori serta literature yang digunakan. Hasil dari penelitian ini adalah bentuk dari analisis dari setiap cover artwork album band GIGI yang masing-masing terdiri dari analisis ketertarikan visual dan tampilan praktis dari setiap karya.

Kata kunci: Cover, Artwork, GIGI, Album

\section{PENDAHULUAN}

GIGI Band berdiri sejak 22 Maret 1994 dan telah menghasilkan paling tidak 13 album studio dan 11 album lainnya.

Dari 13 album utama tersebut, masing-masing memiliki cover artwork yang unik antara satu dengan lainnya dimana setiap cover memiliki image serta makna berbeda. Beberapa cover juga berhubungan langsung dengan judul album yang direpresentasikan.

Secara urut, album utama pertama yang dirilis oleh GIGI adalah album berjudul "Angan" pada tahun 1994. Album kedua berjudul "Dunia" yang dirilis tahun 1995. Album ketiga berjudul " $3 / 4$ " yang dirilis tahun 1996. Album keempat berjudul "2x2" di tahun 1997. Album kelima berjudul "Kilas Balik" di tahun 1998. Album keenam berjudul "Baik" yang dirilis tahun 1999. Album ketujuh berjudul "Untuk Semua Umur" tahun 2001. Album kedelapan berjudul "Salam Kedelapan" pada tahun 2003. Album kesembilan berjudul "Next Chapter" yang dirilis tahun 2006. Album kesepuluh berjudul "Peace, Love, "N Respect" di tahun 2007. Album kesebelas berjudul "GIGI" di tahun 2009. Album keduabelas berjudul "Sweet 17" yang dirilis tahun 2011. Serta album

*email: yerlyana@bundamulia.ac.id 
ketigabelas berjudul "Live at Abbey" di tahun 2014.

Dari satu album ke album lainnya, terdapat perbedaan signifikan dari segi gaya, maupun unsur semiotik dari masingmasing artwork dimana tiap cover berkembang mengikuti arus desain yang kian berbeda tiap periode waktu tertentu. Salah satu perbedaan mendasar adalah konsep less is more serta clarity tiap cover dari tahun ke tahun yang kian lama semakin meningkat.

\section{Identifikasi Masalah}

Beragamnya tampilan cover artwork pada setiap album utama dari GIGI Band baik dari segi desain maupun makna.

\section{Tujuan dan Manfaat Penelitian}

Tujuan dan manfaat dari penelitian ini adalah untuk menganalisis cover artwork pada album-album utama GIGI Band dengan pendekatan teori desain dan teori lainnya yang berkaitan. Adapun manfaat dari penelitian ini adalah agar dimasa depan semaikn banyak cover artwork yang bisa digarap dengan baik, dengan memperhatikan baik unsur desain, makna, maupun segi sentiment yang hendak ditonjolkan.

\section{LANDASAN TEORI}

\section{Teori Desain Komunikasi Visual}

Desain Komunikasi Visual adalah suatu disiplin ilmu yang bertujuan mempelajari konsep-konsep komunikasi serta ungkapan kreatif melalui berbagai media untuk menyampaikan pesan dan gagasan secara visual dengan mengelola elemen-elemen grafis yang berupa bentuk dan gambar, tatanan huruf, serta komposisi warna serta layout (tata letak atau perwajahan). Dengan demikian, gagasan bisa diterima oleh orang atau kelompok yang menjadi sasaran penerima pesan. (Kusrianto, 2007)

\section{Teori Desain}

Desain adalah suatu disiplin atau mata pelajaran yang tidak hanya mencakup eksplorasi visual, tetapi terkait dan mencakup pula dengan aspek-aspek seperti kultura - sosial, filosofis, teknis dan bisnis.

\section{Teori Desain Grafis}

Desain Grafis juga bisa diartikan sebagai suatu konsep pemecahan masalah rupa, warna, bahan, teknik, biaya, guna dan pemakaian yang diungkapkan dalam gambar dan bentuk. Desain grafis dapat didefinisikan sebagai aplikasi dari keterampilan seni dan komunikasi untuk kebutuhan bisnis dan industri (yang biasa disebut seni komersial). Aplikasi-aplikasi ini dapat meliputi periklanan, dan penjualan produk, menciptakan identitas visual untuk institusi, produk dan perusahaan dan lingkungan grafis, desain informasi, secara visual menyempurnakan pesan dalam publikasi.

\section{Teori Prinsip Dasar Desain}

Rumusan prinsip dasar desain merupakan kaidah desain yang berfungsi sebagai sumber acuan dalam mendesain. (Hendratman, 2006)

Prinsip-prinsip desain tersebut yaitu :

\section{Keseimbanga (balance)}

Secara keseluruhan unsur-unsur desain harus tampil dengan seimbang. Ada macam-macam keseimbangan yang bisa digunakan dalam pembuatan suatu desain.

\section{Kesatuan (unity)}

Kesatuan dalam prinsip desain grafis adalah kohesi, konsistensi, ketunggalan atau keutuhan, yang merupakan isi pokok dari komposisi. Dengan prinsip kesatuan dapat membantu semua elemen menjadi sebuah kepaduan dan menghasilkan tema yang kuat, serta mengakibatkan sebuah hubungan yang saling mengikat.

\section{Irama (rhytm)}

Ritme adalah pembuatan desain dengan prinsip yang menyatukan irama. Bisa juga berarti pengulangan atau variasi dari komponen-komponen desain grafis. 


\section{Penekanan (emphasize)}

Setiap bentuk desain ada hal yang perlu ditonjolkan lebih dari yang lain. Tujuan utama dari penekanan ini adalah untuk mewujudkan hal itu sehingga dapat mengarahkan pandangan khalayak sehingga apa yang mau disampaikan tersalur.

\section{Proporsi}

Proporsi dapat diartikan pula sebagai perubahan ukuran/size tanpa perubahan ukuran panjang, lebar, atau tinggi, sehingga gambar dengan perubahan proporsi sering terlihat distorsi.

\section{Teori Unsur-Unsur Visual}

Untuk mewujudkan suatu tampilan visual, diperlukan beberapa unsur yang disusun menjadi karya desain yang selaras, serasi dan seimbang dalam kesatuan, unsurunsur tersebut yaitu titik, garis, bidang, ruang, warna, dan tekstur. (Kusrianto, 2007)

\section{Teori Warna}

Warna merupakan suatu bentuk daya pikat dan bisa menjadi suatu bahasa visual. Warna akan membuat kesan untuk keseluruhan gambar dan dapat memberikan dampak psikologis bagi orang yang melihat.

Dari semua bentuk komunikasi non-verbal, warna merupakan metode paling instan untuk menyampaikan pesan dan makna. Sebelum manusia mengapresiasi nilai estetika warna, mereka telah lebih dahulu menggunakan aspek komunikasi dengan warna. Kemampuan bertahan hidup sangat bergantung pada kemampuan untuk mengidentifikasi objek dan tanda bahaya entah binatang, tumbuhan dan mineral, dan warna menjadi bagian penting dari proses identifikasi. (Eiseman, 2000)

\section{Teori Konunikasi Pendekatan}

Beberapa aspek dari teori komunikasi berdampak pada pembuatan pesan visual. Studi Komunikasi Visual dan pembuatan pesan visual didasari oleh prinsip-prinsip saintifik dan riset empiris dari disiplin-disiplin lain, seperti komunikasi manusia, semiotik, teori informasi psikologi persepsi, sosiologi dan estetika. (Safanayong, 2006)

\section{Teori Semiotika}

Proses semiosis menurut Peirce adalah hubungan segitiga antara tanda, obyek, dan interpretan. Berdasarkan prinsip trikotomi ke-2, hubungan antara obyek dan tanda terbagi menjadi 3 .

1. Ikonik : Apabila tanda menggambarkan obyek. Cotoh tanda ikonik adalah potret seseorang merupakan ikon orang tersebut.

2. Indeks : Apabila tanda sungguh-sungguh dipengaruhi oleh obyek. Contoh tanda indeks adalah ketukan di pintu merupakan indeks dari kedatangan tamu.

3. Simbolik : Apabila tanda mengacu pada obyek berdasarkan aturan-aturan yang telah disepakati. Contoh tanda simbolik adalah simbol-simbol legalitas.

(Desmedt, 2011)

\section{Teori Pengertian Makna (Meaning of Meaning)}

Makna adalah respon internal, diperoleh untuk menstimulir eksternal. Orang memiliki makna yang berbeda-beda untuk kata-kata yang sama. Makna (meaning) dapat berupa pemikiran/gagasan, sebagai persepsi dan reaksi mempengaruhi untuk membangkitkan ransangan kepada seseorang saat disajikan sebuah sign, seperti brand atau objek konsumsi lainnya dalam kaitan (konteks) yang khusus, meaning dalam kata lain adalah subyektif.

Bila tanda tidak memiliki makna/arti, arus pemaknaannya tidak dapat ditransmit. Hanya pesan yang dapat ditransmit dan meaning tidak berada dalam pesan, tetapi dalam penggunaan pesan. Komunikator yang baik memiliki tandatanda verbal dan nonverbal yang memperoleh makna-makna yang diharapkan. Seorang komunikator perlu ekstra hati-hati menggunakan sign yang 
akan membangkitkan makna yang diharapkan untuk sasaran. (Safanayong, 2006)

\section{Teori Korelasi Musik dan Desain Grafis}

Pada tahun 1960an, kesuksesan The Beatles dan potongan rambut mereka yang segera dikenali menuntut desain album untuk lebih bermain berdasarkan pengakuan pembeli dan identifikasi simbolsimbol khas ini. Ini adalah saat yang menyenangkan untuk desain jaket untuk rekaman, karena sampulnya mengambil gambar budaya populer. Ini sangat jelas pada album Sgt. Pepper dengan kecenderungan psikedeliknya.

Juga saat ini, banyak band paling populer memiliki setidaknya satu anggota yang memiliki beberapa pengalaman di dunia seni. Banyak juga yang menugaskan teman/relasi untuk mengerjakan sampul album baru yang menarik.

Tahun 1980an dan 90an telah menyaksikan kemunduran piringan hitam vinil format besar dan munculnya kaset kaset dan compact disk yang lebih kecil. Terbitan dan box sets sering kali mengambil karya seni dari LP yang ada. (Osterer, 1998)

\section{Teori Gambar Dalam Elemen Grafis}

Gambar merujuk pada elemen grafis yang bisa membuat desain terlihat hidup. Baik digunakan sebagai fokus utama halaman atau sebagai cabang elemen, gambar bermain sebagai peran penting dalam mengkomunikasikan pesan dan adapun membentuk bagian kunci dalam membangun identitas visual dalam suatu karya. (Ambrose; Harris, 2005)

\section{Metode Penelitian}

Penelitian ini menggunakan metode kualitatif dimana peneliti melakukan analisis berdasarkan teori-teori yang terkait dengan sumber-sumber buku dan literatur terpercaya. Teori yang digunakan adalah teori prinsip-prinsip dasar desain serta teori semiotika Trikotomi Peirce dengan catatan tanpa tanda simbolik karena masing-masing cover tidak mengandung tanda-tanda yang telah disepakati (simbolik).

\section{HASIL DAN PEMBAHASAN}

Pembahasan analisis tiap cover akan terbagi dari segi prinsip dasar desain, semiotika trikotomi, dan korelasi dengan judul.



\section{Gambar 1 Trikotomi Semiotika Peirce Dalam Cover Artwork Album GIGI (Sumber: Koleksi Pribadi, 2018)}

\section{Analisis Cover Album "Angan"}



Gambar 2 Cover Album "Angan" (Sumber: Situs Resmi GIGI, 2018)

1. Keseimbangan : Peletakan logo GIGI di sisi kiri atas serta judul di kanan bawah membuat komposisi terlihat seimbang. Selain itu juga searah dengan garis imaji yang tercipta dari obyek toilet. 
Kesatuan : Bidang latar pada logo dan judul terlihat menyatu pada elemen gambar berupa foto sehingga seolah memperlihatkan perekat yang terpasang pada sisi foto tersebut.

Penekanan : Elemen yang paling disadari dari cover ini adalah foto toilet itu.

2. Semiotika

\begin{tabular}{|c|c|}
\hline Tanda & Identifikasi Tanda \\
\hline Ikonik & $\begin{array}{l}\text { - } \quad \text { Tulisan "Angan" } \\
\text { pada bagian } \\
\text { kanan bawah. }\end{array}$ \\
\hline Indeks & $\begin{array}{l}\text { Gambar toilet di } \\
\text { tengah rumput. }\end{array}$ \\
\hline
\end{tabular}

3. Korelasi dengan judul :

Penggambaran toilet di tengah rumput yang cenderung surealis dapat dikaitkan dengan kesan 'angan' yang hendak dicapai.

\section{Analisis Cover Album "Dunia"}

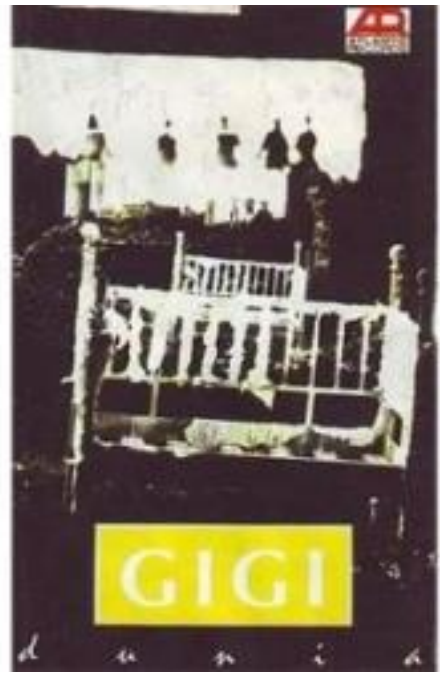

Gambar 3 Cover Album "Dunia" (Sumber: Situs Resmi GIGI, 2018)

1. Keseimbangan : Peletakan elemen foto serta $\log o$ berada tepat ditengah sementara white space pada kedua sisi foto mempuat komposisi bersumbu pada elemen gambar dan juga meringankan komposisi yang cukup berat dari elemen gambar itu sendiri.
Kesatuan : Penggunaan label pada latar logo cukup menggangu mengingat . peletakannya yang terkesan sekedar ditempel pada foto.

Penekanan : Penekanan paling terasa pada obyek kerangka ranjang berdasarkan pada kontras yang ditimbulkan pada latar foto tersebut.

2. Semiotika

\begin{tabular}{|c|c|}
\hline Tanda & Identifikasi Tanda \\
\hline Ikonik & $\begin{array}{l}\text { - Tulisan "Dunia" } \\
\text { pada bagian } \\
\text { bawah logo } \\
\text { GIGI. }\end{array}$ \\
\hline Indeks & $\begin{array}{ll}\text { - } & \text { Gambar } \\
\text { kerangka } \\
\text { ranjang yang } \\
\text { terbengkalai. }\end{array}$ \\
\hline
\end{tabular}

3. Korelasi dengan judul : Makna alam setelah kematian (peristirahatan) pada kerangka ranjang berhubungan dengan kata 'dunia' yang sering kali menjadi faktor manusia melupakan urusan 'surgawi'.

Analisis Cover Album “3/4"

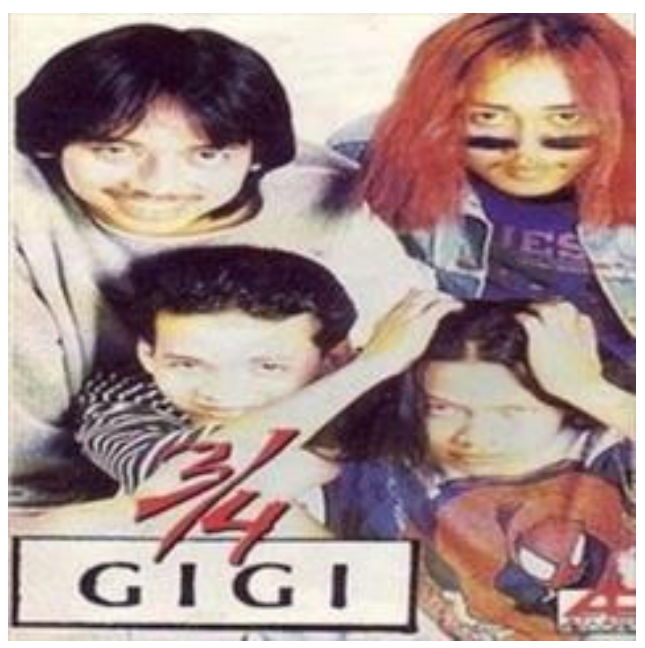

Gambar 4 Cover Album "3/4" (Sumber: Situs Resmi GIGI, 2018)

1. Keseimbangan : Formasi personil yang merupakan four-piece band 
pada dasarnya member kesan seimbang.

Kesatuan

Penggunaan

warna merah, putih dan biru pada elemen foto menyatu dengan elemen judul, logo, maupun latar belakang foto itu sendiri.

Penekanan : Fokus terdapat pada formasi 4 personil.

2. Semiotika

\begin{tabular}{|c|c|}
\hline Tanda & Identifikasi Tanda \\
\hline Ikonik & $\begin{array}{ll} & \text { Tulisan " } 3 / 4 " \\
\text { pada bagian atas } \\
\text { logo GIGI. }\end{array}$ \\
\hline Indeks & $\begin{array}{ll} & \text { Gambar } 4 \\
& \text { personil band } \\
\text { GIGI. } \\
\text { - } \\
\text { Ketidakhadiran } \\
\text { Aria Baron. }\end{array}$ \\
\hline
\end{tabular}

3. Korelasi dengan judul : $\quad 3 / 4$ berhubungan dengan kehadiran album ini sebagai album ke-3, dan juga debut pertama GIGI sebagai four-piece band.

\section{Analisis Cover Album “2x2"}

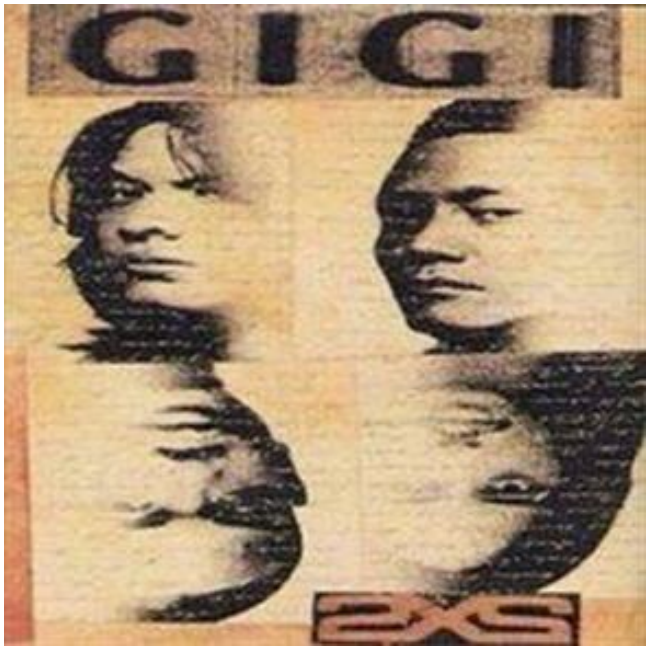

Gambar 5 Cover Album "2x2" (Sumber: Situs Resmi GIGI, 2018)

1. Keseimbangan : Formasi personil yang merupakan four-piece band pada dasarnya member kesan seimbang.
Kesatuan : Kontras antara bidang hitam dari personil dengan pemilihan warna kuning yang usang menyatu dengan baik.

Penekanan : Fokus terdapat pada formasi 4 personil.

2. Semiotika

\begin{tabular}{|c|c|}
\hline Tanda & Identifikasi Tanda \\
\hline Ikonik & $\begin{array}{l}\text { - Tulisan "2x2" } \\
\text { pada bagian } \\
\text { kanan bawah. }\end{array}$ \\
\hline Indeks & $\begin{array}{ll} & \text { Gambar } 2 \\
\text { personil GIGI } \\
\text { menghadap } \\
\text { atas.. } \\
\text { - } \\
\text { Gambar 2 } \\
\text { personil GIGI } \\
\text { menghadap } \\
\text { bawah. }\end{array}$ \\
\hline
\end{tabular}

3. Korelasi dengan judul : 2 personil menghadap atas sementara 2 lainnya menghadap bawah menggambarkan judul 2x2 yang hendak disampaikan serta menegskan formasi GIGI sebagai four-piece band.

\section{Analisis Cover Album "Kilas Balik"}

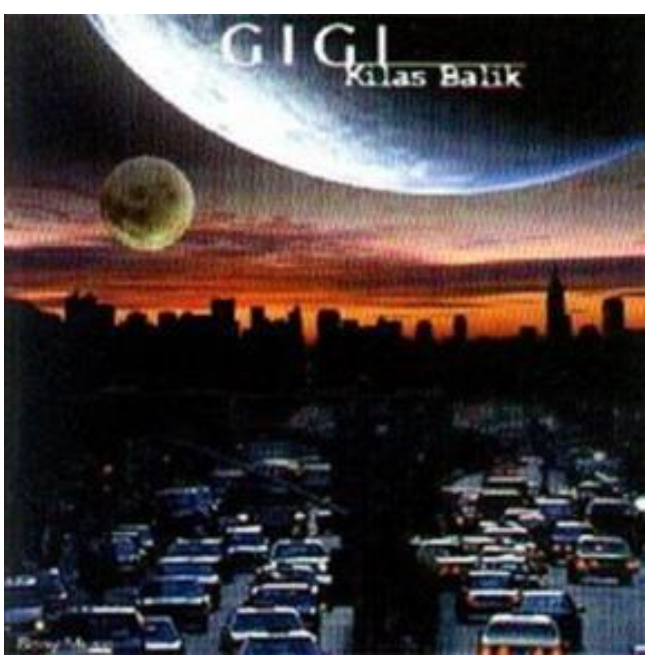

\section{Gambar 6 Cover Album "Kilas Balik"} (Sumber: Situs Resmi GIGI, 2018)

1. Keseimbangan : Keseimbangan ada pada sumbu rule of third. Dapat terlihat dari garis imaji antara 2 jalan serta peletakkan bulan besar. 
Kesatuan : Terdapat pada pemakaian kombinasi warna oranye-biru yang merupakan warna komplementer serta warna hitam yang menonjolkan 2 warna tersebut.

Penekanan : Obyek bulan serta garis horizon adalah hal yang paling mudah disadari dari cover ini.

2. Semiotika

\begin{tabular}{|c|c|}
\hline Tanda & Identifikasi Tanda \\
\hline Ikonik & $\begin{array}{l}\text { - Tulisan "Kilas } \\
\text { Balik" pada } \\
\text { bagian atas. }\end{array}$ \\
\hline Indeks & $\begin{array}{l}\text { - } \quad \text { Gambar } 2 \text { bulan } \\
\text { yang berjauhan. } \\
\text { Gambar jalanan } \\
\text { yang menuju } \\
\text { garis horizon. }\end{array}$ \\
\hline
\end{tabular}

3. Korelasi dengan judul :

Kehadiran 2 bulan serta jalan menuju garis horizon dapat bermakna sebuah rentang waktu. Rentang waktu yang dihadirkan elemen gambar mendukung kata 'kilas balik' yang juga memiliki korelasi dengan waktu.

\section{Analisis Cover Album "Baik"}

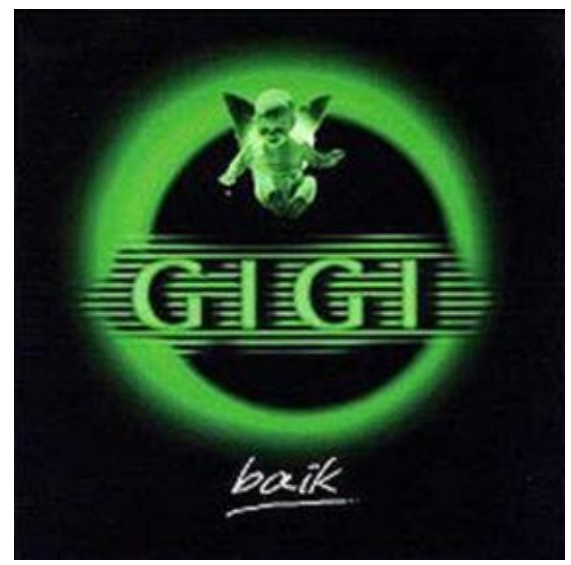

Gambar 7 Cover Album "Baik" (Sumber: Situs Resmi GIGI, 2018)

1. Keseimbangan : Penggunaan lingkaran sebagai pusat serta peletakkan malaikat dengan judul membentuk garis simetris.

Kesatuan : Penggunaan kombinasi warna neon dan hitam sangat tepat.

Penekanan : Fokus terdapat pada logo GIGI sendiri.

2. Semiotika

\begin{tabular}{|c|c|}
\hline Tanda & Identifikasi Tanda \\
\hline Ikonik & $\begin{array}{l}\text { - Tulisan "Baik" } \\
\text { pada bagian } \\
\text { bawah. }\end{array}$ \\
\hline Indeks & $\begin{array}{ll} & \text { Gambar } \\
\text { malaikat } \\
\text { berwujud bayi. } \\
\text { - } \quad \text { Warna hijau } \\
\text { neon (terang) } \\
\text { diatas warna } \\
\text { hitam. }\end{array}$ \\
\hline
\end{tabular}

3. Korelasi dengan judul : Gambar malaikat berwujud bayi dapat menggambarkan kemurnian maupun kesan munafik (sarkasme). Pembatasan pada 2 warna juga menekankan konsep dualisme (baik-buruk) dimana hitam adalah buruk sementara warna terang menjadi kebalikannya. Konsep dualisme pada warna serta adanya malaikat menekankan judul 'baik' yang direpresentasikan malaikat tersebut.

\section{Analisis Cover Album "Untuk Semua Umur"}

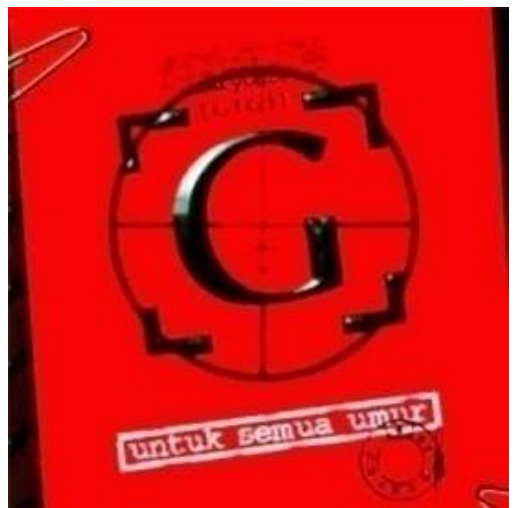

Gambar 8 Cover Album "Untuk Semua Umur"

(Sumber: Situs Resmi GIGI, 2018) 
1. Keseimbangan : Elemen logo dan judul berad tepat di tengah tanpa elemen tambahan yang memberatkan.

Kesatuan : Penggunaan warna merah dan hitam menyatu dengan baik.

Penekanan : Fokus terdapat pada logo GIGI sendiri.

2. Semiotika

\begin{tabular}{|c|cl|}
\hline Tanda & \multicolumn{2}{|c|}{ Identifikasi Tanda } \\
\hline Ikonik & $\bullet$ & $\begin{array}{l}\text { Tulisan "Untuk } \\
\text { Semua Umur" } \\
\text { pada bagian } \\
\text { bawah. }\end{array}$ \\
\hline Indeks & $\bullet$ & $\begin{array}{l}\text { Gambar kertas } \\
\text { berkas. }\end{array}$ \\
& $\bullet$ & $\begin{array}{l}\text { Gambar cap } \\
\text { serta paperclip. } \\
\end{array}$ \\
& $\bullet$ & Warna merah. \\
\hline
\end{tabular}

3. Korelasi dengan judul : Gambar kertas berkas, cap dan paperclip dapat diartikan persoalan legalitas. Sementara warna merah sendiri menekankan kesan restricted yang kerap terkait dengan urusan legal. Penggambaran cover berhubungan secara jukstaposisi dimana 'untuk semua umur' bertabrakan dengan kesan restricted yang ditampilkan.

\section{Analisis Cover Album "Salam Kedelapan"}



\footnotetext{
Gambar 9 Cover Album "Salam Kedelapan"

(Sumber: Situs Resmi GIGI, 2018)
}

1. Keseimbangan : Posisi lampu serta logo berada pada rule of third pada masing-masing sumbu $\mathrm{x}$ dan $\mathrm{y}$.

Kesatuan : Warna pudar pada latar selaras dengan logo yang terkesan blurry.

Penekanan : Fokus terdapat pada logo dan bola lampu disampingnya.

2. Semiotika

\begin{tabular}{|c|c|}
\hline Tanda & Identifikasi Tanda \\
\hline Ikonik & $\begin{array}{l}\text { - Tulisan "Salam } \\
\text { Kedelapan" pada } \\
\text { bagian bawah } \\
\text { logo. }\end{array}$ \\
\hline
\end{tabular}

3. Korelasi dengan judul :

Warna yang tenang, serta bola lampu yang member cahaya dapat bermakna ide ataupun kesempatan. Penggambaran cover kurang berhubungan secara langsung dengan judul. Judul diambil karena album tersebut adalah album kedelapan.

\section{Analisis Cover Album "Next Chapter"}



\section{Gambar 10 Cover Album "Next Chapter"}

(Sumber: Situs Resmi GIGI, 2018) 
1. Keseimbangan : Peletakkan logo, judul, dan elemen foto membentuk sumbu simetris di tengah.

Kesatuan : Perpaduan warna yang lebih gelap serta ekspresi para personil yang serius menimbulkan kesan yang selaras.

Penekanan : Fokus terdapat pada bingkai lingkaran serta Armand diantara personil lainnya.

2. Semiotika

\begin{tabular}{|c|c|}
\hline Tanda & Identifikasi Tanda \\
\hline Ikonik & $\begin{array}{l}\text { Tulisan "Next } \\
\text { Chapter" pada } \\
\text { bagian bawah } \\
\text { logo GIGI. }\end{array}$ \\
\hline Indeks & $\begin{array}{ll}\text { - } & \text { Gambar portal } \\
\text { berupa bingkai } \\
\text { bentuk } \\
\text { lingkaran. } \\
\text { - } \\
\text { Foto personil } \\
\text { GIGI dengan } \\
\text { wajah serius.. } \\
\text { - } \quad \text { Kehadiran Gusti } \\
\text { Hendy } \\
\text { menggantikan } \\
\text { Budhy Haryono. }\end{array}$ \\
\hline
\end{tabular}

3. Korelasi dengan judul : Ekspresi serta gestur serius dari wajah personil, kehadiran Hendy, serta bingkai lingkaran yang membentuk portal menimbulkan kesan 'menyebrang' dari satu sisi ke posisi dimana para personil berada sekarang. Kesan 'menyebrang' menegaskan peralihan yang hendak disampaikan oleh judul 'next chapter'.
Analisis Cover Album "Peace, Love, 'N Respect"

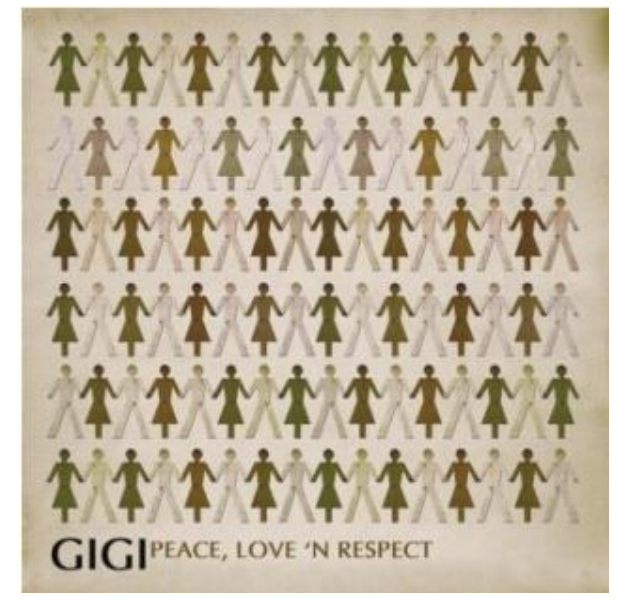

Gambar 11 Cover Album "Peace, Love, 'N Respect"

(Sumber: Situs Resmi GIGI, 2018)

1. Keseimbangan : Elemen pattern membuat komposisi terbagi sama rata.

Kesatuan : Icon manusia yang sederhana ditampilkan dengan baik dengan latar polos sehingga pola tersebut tidak terganggu elemen lainnya.

Penekanan : Fokus terdapat pada pola icon.

2. Semiotika

\begin{tabular}{|c|c|}
\hline Tanda & Identifikasi Tanda \\
\hline Ikonik & $\begin{array}{l}\text { Tulisan "Peace, } \\
\text { Love, "N } \\
\text { Respect" pada } \\
\text { bagian bawah. }\end{array}$ \\
\hline Indeks & $\begin{array}{ll}\text { - } & \text { Gambar icon } \\
\text { manusia saling } \\
\text { bergandengan. } \\
\text { - } \\
\text { Perbedaan } \\
\text { gender dan } \\
\text { warna masing- } \\
\text { masing manusia. }\end{array}$ \\
\hline
\end{tabular}

3. Korelasi dengan judul : Gambar orang yang berbeda gender dibagi ke dalam beberapa shade warna dan saling bergandengan menggambarkan persatuan yang tidak mengenal perbedaan. 
Kesatuan yang tidak mengenal perbedaan ini bersinergi dengan tiga kata pada judul, 'peace', 'love', dan juga 'respect'.

\section{Analisis Cover Album "GIGI”}

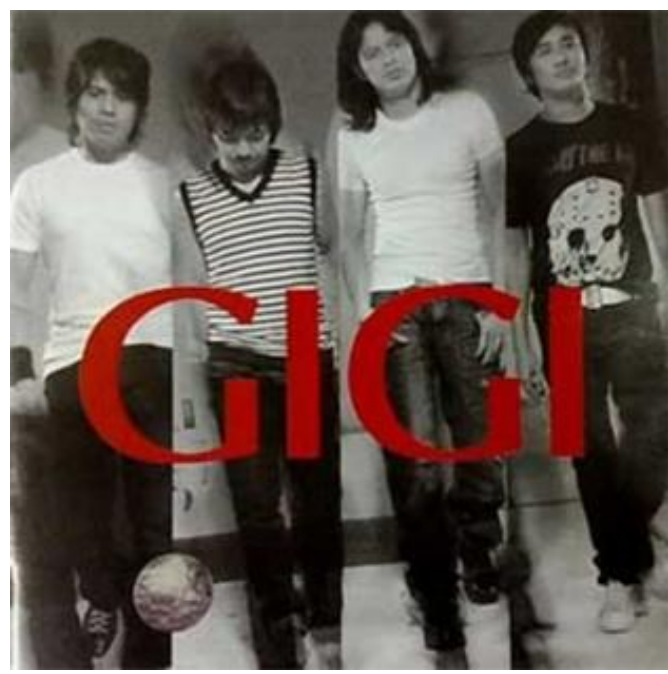

Gambar 12 Cover Album "GIGI" (Sumber: Situs Resmi GIGI, 2018)

1. Keseimbangan : Peletakkan logo, dan formasi personil membentuk kesan sama rata.

Kesatuan : Elemen foto personil dengan judul/logo selaras (4 personil, 4 huruf).

Penekanan : Fokus terdapat pada logo/judul.

2. Semiotika

\begin{tabular}{|c|l|}
\hline Tanda & \multicolumn{2}{|c|}{ Identifikasi Tanda } \\
\hline Ikonik & $\bullet \begin{array}{l}\text { Tulisan "GIGI" } \\
\text { pada bagian } \\
\text { tengah. }\end{array}$ \\
\hline Indeks & $\begin{array}{l}\text { Gambar foto 4 } \\
\text { personil GIGI } \\
\text { secara utuh. }\end{array}$ \\
\hline
\end{tabular}

3. Korelasi dengan judul : Tidak ada sisi lain yang ditawarkan selain karakter masing-masing personil. Personil ditampilkan secara utuh demi menampilkan karakter secara utuh pula. Korelasi secara langsung hendak memperlihatkan kesan bahwa 'inilah GIGI' tanpa ada pernak pernik lain yang mengganggu.

\section{Analisis Cover Album "Sweet 17"}



Gambar 13 Cover Album "GIGI" (Sumber: Situs Resmi GIGI, 2018)

1. Keseimbangan : Keseluruhan elemen dipusatkan ke sumbu tengah dimana terdapat judul, gambar personil, serta bidang persegi berwarna merah.

Kesatuan : Penggunaan ilustrasi serta efek-efek warna pada personil memperkuat kesan komikal cover ini.

Penekanan : Fokus terdapat pada ilustrasi Armand.

2. Semiotika

\begin{tabular}{|c|c|}
\hline Tanda & Identifikasi Tanda \\
\hline Ikonik & $\begin{array}{l}\text { - Tulisan "Sweet } \\
\text { 17" pada bagian } \\
\text { bawah logo } \\
\text { GIGI. }\end{array}$ \\
\hline Indeks & $\begin{array}{ll}\text { - } & \text { Gambar ilustrasi } \\
\text { komikal } 4 \\
\text { personil GIGI } \\
\text { secara utuh. } \\
\text { Gambar ilustrasi } \\
\text { komikal 4 } \\
\text { personil GIGI } \\
\text { secara close up. } \\
\text { Efek-efek warna } \\
\text { dan cahaya. }\end{array}$ \\
\hline
\end{tabular}


3. Korelasi dengan judul : Personil digambarkan heroik, dapat diartikan sebagai fase dimana remaja akhir mencari sosok panutan serta angan-angan yang juga tinggi.

Sifat-sifat fase yang dijelaskan sebelumnya mendukung judul 'sweet 17' dimana usia 17 tahun bertepatan dengan fase tersebut.

\section{Analisis Cover Album "Live at Abbey"}

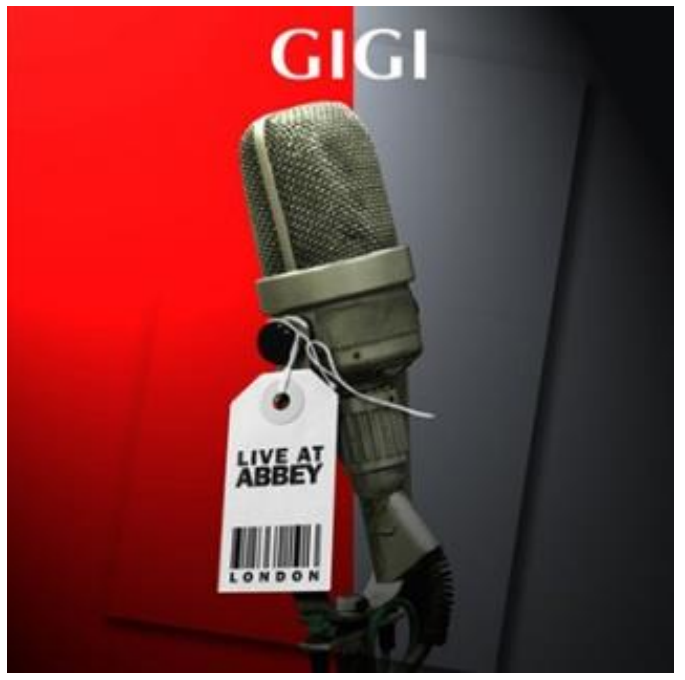

Gambar 14 Cover Album "Live at Abbey"

(Sumber: Situs Resmi GIGI, 2018)

1. Keseimbangan : Keseluruhan elemen dipusatkan ke sumbu tengah dimana terdapat judul, gambar mic, serta judul yang diletakkan pada paper tag.

Kesatuan : Elemen-elemen foto yang digunakan lebih sederhana dan nyata tanpa ada tambahan elemen gambar yang bersifat kartunis.

Penekanan : Fokus terdapat pada gambar mic.

2. Semiotika

\begin{tabular}{|c|cl|}
\hline Tanda & \multicolumn{2}{|c|}{ Identifikasi Tanda } \\
\hline Ikonik & $\bullet \begin{array}{l}\text { Tulisan "Live at } \\
\text { Abbey" pada } \\
\text { bagian papertag. }\end{array}$ \\
\hline Indeks & $\bullet \begin{array}{l}\text { Gambar mic } \\
\text { studio rekaman. }\end{array}$ \\
\hline
\end{tabular}

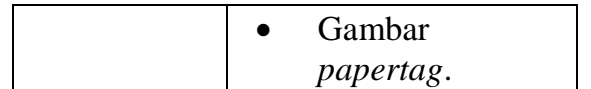

3. Korelasi dengan judul :

Kehadiran mic serta paper tag menggambarkan situasi nyata, langsung, serta aktual. Keadaan 'nyata' serta 'langsung' yang disampaikan lewat gambar berhubungan langsung dengan kata 'live' dari judul album ini sendiri.

\section{SIMPULAN DAN SARAN}

Dapat disimpulkan bahwa cover artwork GIGI dari masa ke masa mengalami perkembangan baik dari segi desain maupun makna dari segi kritis kearah yang lebih personal. Dari segi eyecatching dan komposisi dapat terlihat penyesuaian di tiap era dimana kesan less is more semakin ditunjukkan. Beberapa cover cenderung menekankan formasi four-piece personil band. Penggunaan gambar-gambar juga semakin literal tanpa pemaknaan yang rumit.

Penulis berharap penggarapan cover artwork dapat terus menggunakan unsur pemaknaan pada elemen-elemen yang ditampilkan tanpa perlu mengesampingkan arus desain yang ada.

\section{Daftar Pustaka}

Ambrose, G \& Harris, P. (2005).Basics Design 04: Image.London: Thames \& Hudson.

Eiseman, L. (2000). PANTONE Guide to Communicating with Color. Ohio: HOW Books.

Kusrianto, A. (2007). Pengantar Desain Komunikasi Visual. Yogyakarta: Andi Offset.

Safanayong, Y. (2006). Desain Komunikasi Visual Terpadu. Jakarta: Arte Intermedia. 
Sihombing, Danton. (2001). Tipografi dalam Desain Grafis. Jakarta: PT

Desmedt, Nicole Everaert. (2011). Peirce's Semiotics. Quebec: Rimouski Retrieve from http://www.signosemio.com/peirce/s emiotics.asp
Gramedia Pustaka Utama.

\section{Daftar Literatur Penunjang}

Irv, Osterer. (1998, Mei 1). Recorded Music and Graphic Design Vol. 123, Issue 4, Pg. 18. Retrieve from http://eresources.perpusnas.go.id

www.gigibandofficial.com. diakses pada 22 Februari 2018 